\title{
Functional Analysis of Gene-Silencing Suppressors from Tomato Yellow Leaf Curl Disease Viruses
}

\author{
Ana P. Luna, ${ }^{1}$ Gabriel Morilla, ${ }^{2}$ Olivier Voinnet, ${ }^{2}$ and Eduardo R. Bejarano' \\ ${ }^{1}$ Instituto de Hortofruticultura Subtropical y Mediterránea "La Mayora" (IHSM-UMA-CSIC), Departamento de Genética, \\ Facultad de Ciencias, Universidad de Málaga, Campus de Teatinos s/n, E-29071 Málaga, Spain; ${ }^{2}$ Institut de Biologie \\ Moléculaire des Plantes du Centre National de la Recherche Scientifique, 67084 Strasbourg Cedex, France
}

Submitted 26 April 2012. Accepted 1 June 2012.

\begin{abstract}
Tomato yellow leaf curl disease (TYLCD) is caused by a complex of phylogenetically related Begomovirus spp. that produce similar symptoms when they infect tomato plants but have different host ranges. In this work, we have evaluated the gene-silencing-suppression activity of $\mathrm{C} 2, \mathrm{C} 4$, and V2 viral proteins isolated from the four main TYLCDcausing strains in Spain in Nicotiana benthamiana. We observed varying degrees of local silencing suppression for each viral protein tested, with $\mathrm{V} 2$ proteins from all four viruses exhibiting the strongest suppression activity. None of the suppressors were able to avoid the spread of the systemic silencing, although most produced a delay. In order to test the silencing-suppression activity of Tomato yellow leaf curl virus (TYLCV) and Tomato yellow leaf curl Sardinia virus (TYLCSV) proteins in a shared (tomato) and nonshared (bean) host, we established novel patch assays. Using these tools, we found that viral proteins from TYLCV were able to suppress silencing in both hosts, whereas TYLCSV proteins were only effective in tomato. This is the first time that viral suppressors from a complex of diseasecausing geminiviruses have been subject to a comprehensive analysis using two economically important crop hosts, as well as the established $N$. benthamiana plant model.
\end{abstract}

Geminiviruses constitute a large family of plant viruses with circular, single-stranded (ss)DNA genomes, packaged within geminate particles that can infect a broad range of plants (Rojas et al. 2005; Seal et al. 2006). The Geminiviridae family is divided into four genera-Begomovirus, Curtovirus, Topocuvirus, and Mastrevirus - based on their genome organization, host range, and insect vectors (Fauquet et al. 2008). The genus Begomovirus contains the majority of geminivirus species. Members of this genus have either monopartite or bipartite genomes, are transmitted by the whitefly Bemisia tabaci, and infect a wide range of dicots in both the Old and the New World (Rojas et al. 2005). Tomato yellow leaf curl disease (TYLCD) is caused by a complex of phylogenetically related Begomovirus spp. that produce similar symptoms when they infect tomato plants (Díaz-Pendón et al. 2010). TYLCD-asso-

Current address for O. Voinnet: Swiss Federal Institute of Technology Zurich, Department of Biology Chair of RNA biology, LFW D 17.3, Universitätstr. 2 8092, Zurich, Switzerland.

Corresponding author: E. R. Bejarano; E-mail: Edu_rodri@uma.es

* The $\boldsymbol{e}$-Xtra logo stands for "electronic extra" and indicates that eight supplementary figures and four supplementary tables are published online and that Figure 5 appears in color online. ciated viruses are usually monopartite, having a single genomic component that resembles DNA A. Their genomes encode the replication-associated protein Rep (also named $\mathrm{C} 1$ ), the transcription activator protein $\mathrm{C} 2$ (also named TrAP), the replication enhancer protein C3 (also named REn), two proteins (C4 and V2) associated with pathogenicity and virus-host interactions, and the coat protein $(\mathrm{CP})$. Open reading frames $(\mathrm{ORF})$ are organized bi-directionally and are separated by an intergenic region (IR) that contains key elements for initiating replication and transcription of the viral genome (Hanley-Bowdoin et al. 2000) (Fig. 1).

TYLCD epidemics have occurred in the Western Mediterranean Basin since the late 1980s. In Spain, the first reports of infection in the early 1990s were associated with the Spain (ES) strain of Tomato yellow leaf curl Sardinia virus (TYLCSV) (Noris et al. 1994; Reina et al. 1994). Subsequent introduction of isolates of the Israeli severe and mild strains of Tomato yellow leaf curl virus (TYLCV and TYLCV-Mld, respectively) (Morilla et al. 2003; Navas-Castillo et al. 1997) resulted in novel sources of variation. In fact, only 2 years after the detection of TYLCV, a novel, recombinant variant named Tomato yellow leaf curl Malaga virus (TYLCMalV) emerged as a consequence of genetic exchange between TYLCSV and TYLCVMld isolates (Monci et al. 2002).

Host range studies have shown that 13 plant species from six botanical families are susceptible to TYLCD-associated viruses, including Solanum lycopersicum and Nicotiana benthamiana (Cohen and Antignus 1994; Cohen and Nitzany 1966). In addition to tomato, TYLCV infections have also been detected in other crops such as common bean and pepper (Navas-Castillo et al. 1999; Reina et al. 1999; Roye et al. 1999). Differential host specificity is exhibited by distinct TYLCD-associated species. For example, common bean can be infected by TYLCV, TYLCV-Mld, and TYLCMalV but not by TYLCSV (GarcíaAndrés et al. 2007a; Monci et al. 2002; Sánchez-Campos et al. 1999). Similarly, TYLCV is able to infect Capsicum annuum and $C$. chinense, while TYLCV-Mld can only infect $C$. annuum, and TYLCSV is unable to replicate in any Capsicum sp. (Morilla et al. 2005; Polston et al. 2006).

The ability of a plant virus to effectively infect a particular host depends on the balance between host defenses and virus multiplication. Among host defense responses, RNA silencing has emerged as an important antiviral mechanism in plants. RNA silencing refers to a homology-dependent gene-silencing mechanism guided by small RNAs (18 to 25 nucleotides [nt] long), including short interfering RNAs (siRNAs) and microRNAs (miRNAs). Upon infection, plants can process viral RNA into siRNAs and use them to direct specific antiviral silencing activity. Several lines of evidence, especially from 
studies into siRNAs and viral pathogenesis, have led to the current view of cytoplasmic RNA silencing, generally referred to as post-transcriptional gene silencing (PTGS), as a ubiquitous defense against RNA viruses and transcripts produced by DNA viruses. In addition, viral chromatin is subject to repressive methylation directed by siRNAs that leads to transcriptional gene silencing. For a comprehensive picture of plantsilencing pathways, there are several excellent reviews (Ding 2010; Llave 2010; Ruíz-Ferrer and Voinnet 2009). The ferocity of the never-ending molecular "arms race" between hosts and pathogens is revealed by the fact that all of the plant viruses examined to date encode at least one protein able to suppress plant antiviral silencing. Viral suppressors can interfere with plant gene silencing at several different steps, including siRNA production, siRNA-effector complex loading, or the expression of gene-silencing pathway proteins (Díaz-Pendón and Ding 2008; Raja et al. 2010; Rodrigo et al. 2011).

Although there is a large amount of information about suppressors encoded by RNA viruses, comparatively little is known about the activities of silencing suppressors from DNA viruses. Since the first description of geminivirus C2 proteins as silencing suppressors (Voinnet et al. 1999), several reports have shown that Begomovirus $\mathrm{C} 4$ and $\mathrm{V} 2$ proteins can also function as PTGS suppressors. C2 is an approximately $15-\mathrm{kDa}$ protein initially characterized as a transcription factor that stimulates the expression of viral late genes (Sunter and Bisaro 1991, 1992) and which also triggers host gene transactivation (Trinks et al. 2005). This protein is not essential for DNA replication and, in the case of TYLCSV, is even dispensable for $N$. benthamiana infectivity. However, TYLCSV C2 is required to infect tomato (Wartig et al. 1997). Several studies have demonstrated the capacity of C2 to reverse PTGS and prevent the systemic spread of silencing, which depends on the ability of the protein to stimulate the transcription of host genes that negatively regulate silencing pathways (Dong et al. 2003; Trinks et al. 2005; Van Wezel et al. 2002), a mechanism termed transcription-dependent silencing suppression (Bisaro 2006). Evidence that Begomovirus C2 can also suppress PTGS in a transcriptionindependent manner through the inhibition of adenosine kinase (ADK) was obtained from transient local silencing studies using $N$. benthamiana leaves (Wang et al. 2005; Yang et al. 2007).

C4 is a pathogenicity determinant that localizes to the plasma membrane (Sharma and Ikegami 2008), and has been linked to viral movement (Rojas et al. 2001) and gene-silencing suppression (Vanitharani et al. 2004). The PTGS suppression activities of $\mathrm{C} 4$ proteins were first demonstrated in a study in $N$. benthamiana leaf assays of two different cassava-infecting Begomovirus spp., African cassava mosaic virus (ACMV) and East-African cassava mosaic virus (EACMV) (Vanitharani et al. 2004). The C4 suppression mechanism was determined from the finding that the silencing-active protein associates with ss but not double-stranded (ds) siRNAs and miRNAs in vitro and in vivo (Chellappan et al. 2005).

The V2 protein, unique to most Old World Begomovirus spp., functions as an RNA-silencing suppressor that inhibits the innate immune response of the host plant, and has a role in the elicitation of hypersensitive response (HR)-like cell death (Amin et al. 2011; Sharma and Ikegami 2010; Sharma et al. 2010; Zrachya et al. 2007). It has been proposed that V2 suppresses PTGS by interfering with siRNA amplification through either direct interaction with suppressor of gene silencing 3 or competition for dsRNA substrate (Fukunaga and Doudna 2009; Glick et al. 2008).

In recent years, several studies have determined the silencing-suppression activity of $\mathrm{C} 2, \mathrm{C} 4$, and $\mathrm{V} 2$ proteins from different Begomovirus spp. These analyses have confirmed that individual geminiviruses can encode more than one suppressor and that similar proteins from different viruses do not have equivalent suppressor activities (Amin et al. 2011; ChowdaReddy et al. 2008; Gopal et al. 2007; Nawaz-Ul-Rehman et al. 2010; Sharma et al. 2010; Zrachya et al. 2007). However, because all of these results have been obtained using $N$. benthamiana-based assays, no data are yet available regarding the suppressor activity of these proteins in other plant species and the possible relationship between observed differences in virulence and the host range of closely related species.

In the present work, we have determined the PTGS suppression activity of $\mathrm{C} 2, \mathrm{C} 4$, and V2 proteins from Spanish TYLCD viruses that differ in symptom severity and host range. First, using $N$. benthamiana plants, we evaluated the capacity of the viral proteins to suppress gene silencing at local and systemic levels. Then, to determine whether the silencing-suppression activity of the viral proteins is host dependent and whether there is a correlation between this activity and the capacity of the virus to infect the plant, we have developed assays that allow PTGS to be studied in two natural hosts of agronomical importance: tomato and bean. Using these assays, we tested PTGS suppression mediated by $\mathrm{C} 2, \mathrm{C} 4$, and V2 from two TYLCD viruses that differ in the severity of symptoms they induce in tomato and their ability to infect bean. This is the first time that the silencing-suppression activity of viral proteins has been tested using a patch assay with crop plants such as tomato and bean.

\section{RESULTS}

Analysis of RNA-silencing-suppressor activity of $\mathrm{C2}, \mathrm{C} 4$, and $\mathrm{V} 2$ from TYLCD viruses in N. benthamiana.

To identify potential RNA-silencing suppressors in the viruses that cause TYLCD in Spain, ORF of $C 2, C 4$, and $V 2$ from Spanish isolates of TYLCSV, TYLCV, TYLCV-Mld, and TYLCMalV were cloned into binary vectors. These expression vectors were employed to evaluate the gene-silencing-suppressor activity using assays in wild-type or 16c (transgenic plants constitutively expressing green fluorescent protein [GFP]) $N$. benthamiana lines (Hamilton et al. 2002).

In the first assay, wild-type $N$. benthamiana leaves were coinfiltrated with two cultures containing a binary construct that expresses GFP (pBin-35S-mGFP5) (Haseloff et al. 1997) and the desired viral coding sequence under the control of the Cauliflower mosaic virus 35S promoter (CaMV 35S) (Llave et al. 2000). Co-infiltration of 35S-GFP with the empty binary vector or a plasmid expressing the P19-silencing suppressor from $\mathrm{To}_{0}$ mato bushy stunt virus (TBSV) (Voinnet et al. 1999) were used

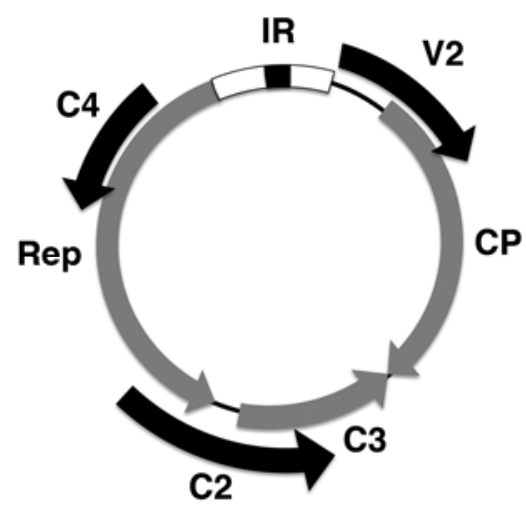

Fig. 1. Genome organization of Tomato yellow leaf curl disease viruses. Map of the Tomato yellow leaf curl virus-like genome showing the open reading frames coded by the virus sense (V2 and coat protein $[C P])$ and complementary sense (replication-associated protein [Rep], C4, C2 or transcription activator protein, and $C 3$ or replication enhancer protein) strands. 
as negative and positive controls, respectively. Leaf discs were cut out of the infiltrated tissues and observed under ultraviolet (UV) light. As previously described, infiltrated patches with 35S-GFP and P19 displayed stronger green fluorescence than tissues infiltrated with $35 \mathrm{~S}-\mathrm{GFP}$ and the empty vector, where fluorescence is decreased as result of the activation of GFP RNA silencing (Brigneti et al. 1998; Voinnet et al. 2000) (Fig. 2A).

Of the 12 geminiviral proteins tested, increased fluorescence relative to the negative control was clearly visible for all four $\mathrm{V} 2$ constructs. Interestingly, the increase in fluorescence observed for $\mathrm{V} 2$ proteins, with the exception of the one isolated from TYLCMalV, was similar to that of P19. Weaker but detectable increases in fluorescence were also observed for most $\mathrm{C} 2$ and $\mathrm{C} 4$, with the exception of $\mathrm{C} 4$ from TYLCMalV and $\mathrm{C} 2$ from TYLSCV and TYLCV (Fig. 2A). Our visual observations were confirmed by Western blot analysis using an antiGFP antibody (Fig. 2B). As expected, all V2 proteins produced an increase in GFP accumulation compared with the negative control. Enhancement of GFP expression generated by V2 from TYLCSV, TYLCV, and TYLCV-Mld was as strong or even stronger than that produced by P19. In contrast, expression of $\mathrm{C} 2$ and $\mathrm{C} 4$ proteins had only a small effect on GFP levels, or no effect for the C4 from TYLCV-Mld and C2 from TYLCSV and TYLCV. The hallmark of PTGS is the appearance of 21- to 24-nt siRNAs in the silenced tissue (Hamilton and Baulcombe 1999). To assess whether co-expression of viral proteins had an effect on siRNA accumulation, relative levels of the GFP-specific siRNAs were determined. The amount of siRNAs present in tissues agroinfiltrated with constructs for the expression of $\mathrm{C} 2$ or $\mathrm{C} 4$ were not significantly different from the negative control (Fig. 2B). However, in all cases except for TYLCMalV, a decrease in GFP siRNA was observed when V2 proteins were expressed (Fig. 2B). This reduction was particularly evident in the case of V2 from TYLCV-Mld (quantified in Supplementary Fig. S1B). Previously, Zrachya and associates (2007) claimed that V2 from an Israeli isolate of TYLCV could strongly suppress GFP PTGS in N. benthamiana but without apparent effects on the accumulation of GFP-specific siRNAs. Because there are no differences in the amino-acid sequence between the V2 isolate from TYLCV used here and the one employed by Zrachya and associates, the apparent discrepancy in the siRNA accumulation could be explained by the modest reduction in siRNA accumulation produced by our isolate and by the fact that Zrachya and associates did not quantify siRNA levels in their assay.

We tested the expression levels of all of the $C 2, C 4$, and $V 2$ cassettes in the analyzed tissue by Northern blot (Supplementary Fig. S2), confirming that the inability to suppress gene silencing of certain $\mathrm{C} 2$ and $\mathrm{C} 4$ proteins is unrelated to mRNA accumulation.

To determine the effect of geminiviral proteins on both local and systemic PTGS, leaves from $N$. benthamiana $16 \mathrm{c}$ plants were agroinfiltrated with constructs for the expression of $35 \mathrm{~S}$ GFP and the viral protein under test. P19 and an empty vector were used as controls. Examination of the fluorescence of infiltrated leaves 4 days postinfiltration (dpi) showed the same results as wild-type $N$. benthamiana leaves (Fig. 3A). The
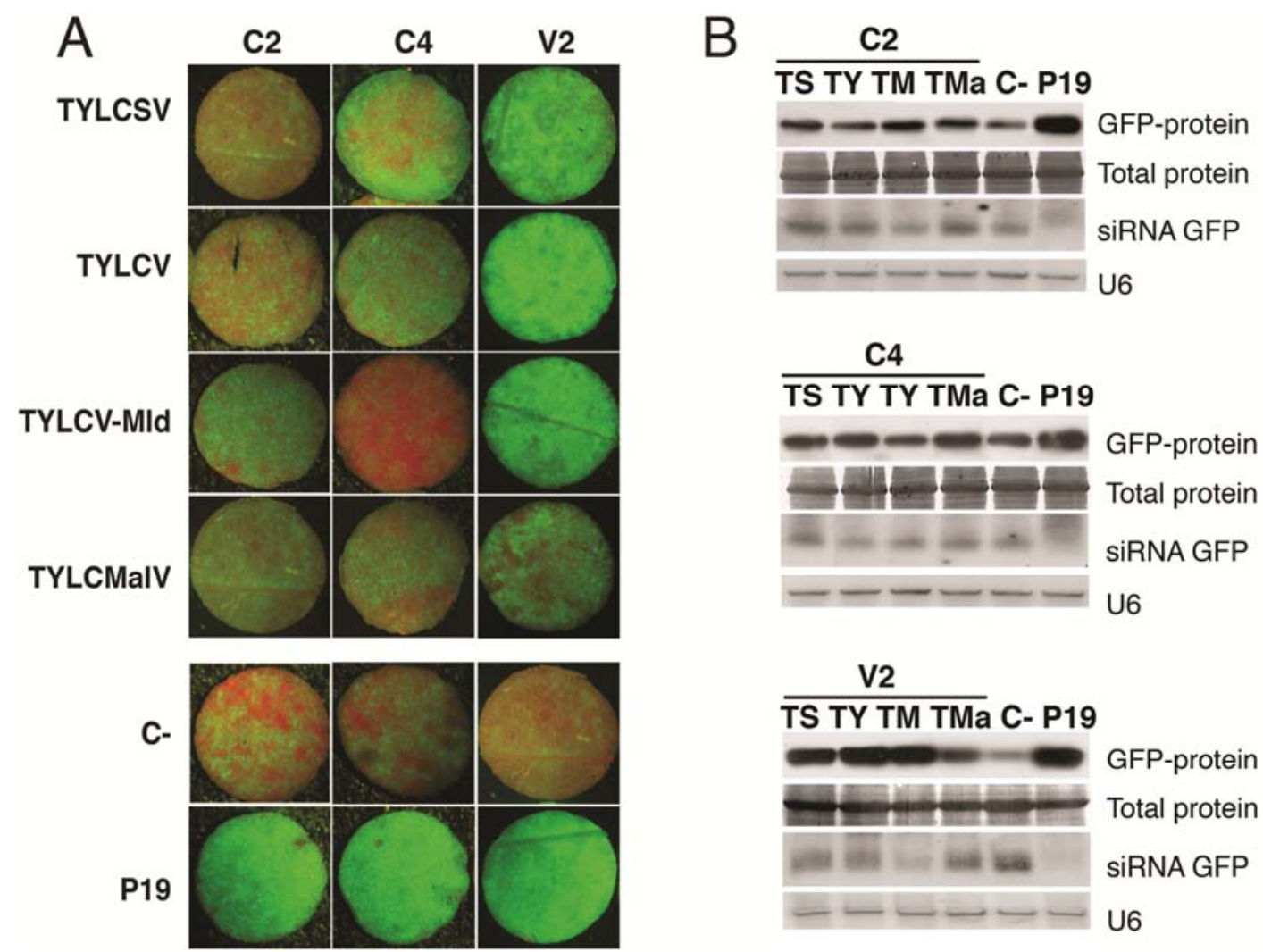

Fig. 2. Local post-transcriptional gene silencing suppression activity in Nicotiana benthamiana plants. A, Leaf discs (10 mm in diameter) from $N$. benthamiana plants infiltrated with a mixture of two different Agrobacterium tumefaciens cultures expressing green fluorescent protein (GFP) and the viral proteins C2, C4, and V2 from the four studied Tomato yellow leaf curl disease isolates: Tomato yellow leaf curl Sardinia virus (TYLCSV), Tomato yellow leaf curl virus (TYLCV), TYLCV-mild (Mld), and Tomato yellow leaf curl Malaga virus (TYLCMalV), photographed under UV light at 4 days postinfiltration (dpi). P19 and the empty vector (C-) were used as a positive and negative control, respectively. B, Molecular analysis of tissues expressing C2, C4, and V2 from TYLCSV (TS), TYLCV (TY), TYLCV-Mld (TM), and TYLCMalV (TMa) at 4 dpi. Total proteins were subjected to sodium dodecyl sulfate polyacrylamide gel electrophoresis and immunoblot analysis with anti-GFP antibody. Coomassie blue staining of the protein blot is shown as loading control. Total RNA was subjected to Northern blot analysis to detect GFP short interfering (si)RNAs and sRNA U6 as loading control. 
strongest increases in GFP-fluorescence were observed for coinfiltration with the V2 constructs which all had an effect similar to P19. Expression of C2 and C4 produced slight increases in fluorescence (or none at all in the case of TYLCV-Mld C4). Agroinfiltrated 16c plants were also used to study whether viral proteins can block the cell-to-cell spread of RNA silencing by monitoring GFP expression in the cells surrounding agroinfiltrated patches. If the silencing signal exits from the agroinfil- trated area, the cell-to-cell movement causes a strong decrease in GFP expression, triggering the appearance of a red ring around the infiltrated patch (Himber et al. 2003). In the plants infiltrated with $35 \mathrm{~S}-\mathrm{GFP}$ and with an empty vector, silencing was induced rapidly, and a red fluorescent ring was formed around the infiltrated area within $5 \mathrm{dpi}$. In contrast, no red ring was formed in the control leaves expressing both 35S-GFP and P19 (Himber et al. 2003; Silhavy et al. 2002). Significantly, we
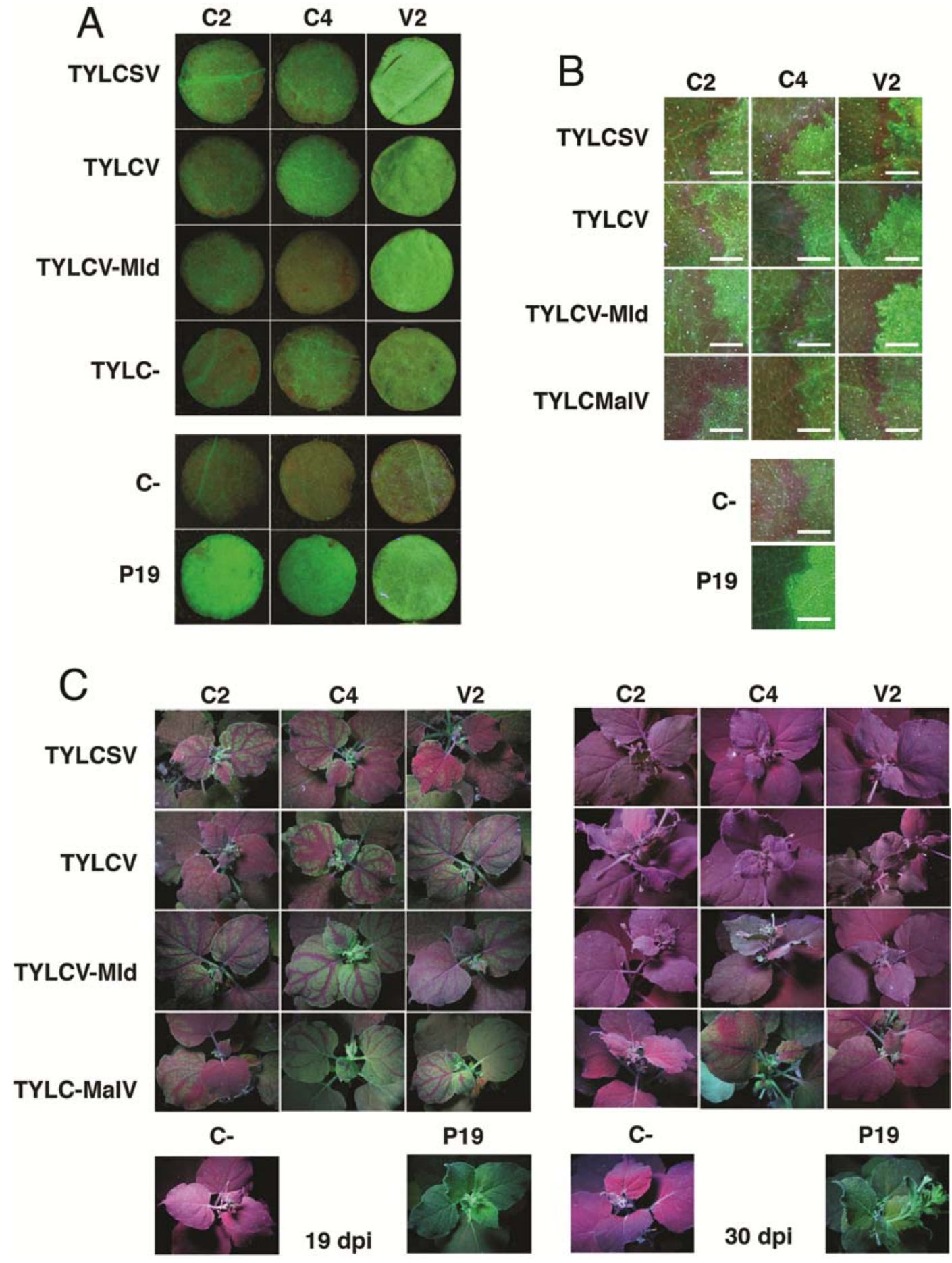

Fig. 3. Systemic and nonautonomous post-transcriptional gene silencing suppression activity in 16c Nicotiana benthamiana plants. A, Leaf discs (10 mm in diameter) from 16c $N$. benthamiana plants infiltrated with a mixture of two different Agrobacterium tumefaciens cultures expressing green fluorescent protein (GFP) and the viral proteins C2, C4, and V2 from the four studied Tomato yellow leaf curl disease isolates: Tomato yellow leaf curl Sardinia virus (TYLCSV), Tomato yellow leaf curl virus (TYLCV), TYLCV-mild (Mld), and Tomato yellow leaf curl Malaga virus (TYLCMalV), photographed under UV light at 4 days postinfiltration (dpi). P19 and the empty vector (C-) were used as positive and negative controls, respectively. B, GFP expression in the cells surrounding the agroinfiltrated patches at $5 \mathrm{dpi}$. Bar, $2 \mathrm{~mm}$. C, Study of systemic GFP silencing. Agroinfiltrated 16c plants were photographed under UV light at 19 and $30 \mathrm{dpi}$ (left and right panel, respectively). 
observed the appearance of the red ring around the infiltrated area for all of the geminiviral proteins tested (Fig. 3B). These results suggest that none of the tested TYLCD-associated virus proteins can suppress the short-range (cell-to-cell) spread of gene silencing.

Infiltrated plants were monitored under UV light for the initiation of systemic silencing in the newly emerging leaves. After 19 dpi, systemic silencing was almost complete in plants infiltrated with $35 \mathrm{~S}-\mathrm{GFP}$ plus empty vector while GFP expression persisted in all newly emerged leaves when co-infiltrated with P19. Although systemic RNA silencing was eventually observed in plants infiltrated with all of the geminivirus constructs, silencing was delayed in most cases, especially in plants infiltrated with constructs expressing C4 from TYLCV-Mld and TYLCMalV (Fig. 3C, left panel). At 30 dpi, only plants agroinfiltrated with the geminivirus construct expressing TYLCMalV C4 still retained some GFP-expressing areas in newly emerging leaves. In contrast, plants infiltrated with P19 retained strong GFP expression in all of the tissues, even at 30 dpi (Fig. 3C, right panel). Together, these results demonstrate that, while some geminivirus proteins could delay the long-distance spread of the RNA-silencing signal, none of them could block the process completely.

To complete our $N$. benthamiana-based analysis of the suppressor activity of geminiviral proteins, we next used a Potato virus $X$ (PVX)-derived vector to express $\mathrm{C} 2, \mathrm{C} 4$, and V2 proteins in all plant tissues. Viral ORF were expressed from the vector pGR107 and tested individually in 16c N. benthamiana leaves co-infiltrated with a 35S-GFP-expressing Agrobacterium tumefaciens culture. Co-agroinoculation of 35S-GFP with either the empty PVX vector or a recombinant PVX virus

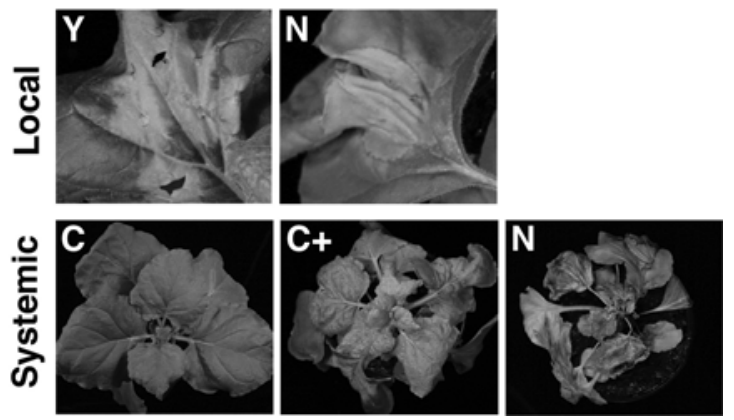

Fig. 4. Examples of local and systemic symptoms induced by Potato virus $X$ (PVX) expression of $\mathrm{C} 2, \mathrm{C} 4$, and $\mathrm{V} 2$ in Nicotiana benthamiana plants. Local symptoms: yellowing $(\mathrm{Y})$ or a necrosis $(\mathrm{N})$ of the agroinfiltrated area. Systemic symptoms: mild symptoms typical of a PVX infection (C), enhanced PVX symptoms (C+), or systemic necrosis $(\mathrm{N})$. expressing a gene-silencing suppressor (nonstructural protein) from Tomato spotted wilt virus were used as negative and positive controls, respectively (Bucher et al. 2003; Takeda et al. 2002). The results obtained at local and systemic levels are summarized in Figure 4 and Table 1. As previously reported for several viral suppressors, the expression of certain geminiviral proteins from a heterologous virus alters symptom severity (Brigneti et al. 1998; Cañizares et al. 2008). Tissues infiltrated with PVX expressing any of the $\mathrm{C} 4$ or $\mathrm{C} 2$ proteins, except $\mathrm{C} 2$ from TYLCSV, developed the local yellowing symptoms typical of PVX, while all the V2 proteins, C2 from TYLCSV, and nonstructural proteins all caused necrosis.

At a systemic level, PVX infection resulted in mild mosaic symptoms that gradually became asymptomatic in some leaves as a result of recovery from viral infection. In contrast, $N$. benthamiana plants inoculated with PVX expressing any of the V2 proteins or C2 from TYLCSV exhibited much more severe symptoms and did not recover from viral infection, dying at 8 to $10 \mathrm{dpi}$. PVX-mediated expression of any of the $\mathrm{C} 4$ proteins (except C4 from TYLCMalV) or C2 from TYLCMalV generated a remarkable worsening of the symptoms, causing typical geminivirus-like symptoms in systemically infected leaves, including mosaic, curling, folding, distortion, and size reduction. On the other hand, expression of C2 from TYLCV and TYLCVMld induced symptoms that were indistinguishable from those produced by PVX alone.

Exacerbation of the symptoms produced by recombinant PVX viruses expressing other viral proteins has been linked to an increase in the accumulation of PVX genomic RNA in infected plants (Cañizares et al. 2008; Zhang et al. 2012). To determine whether this also happened with geminiviral proteins, apical leaves from infected plants that did not show necrosis were taken at 8 to $10 \mathrm{dpi}$ and total RNA extracted. Reverse-transcriptase polymerase chain reaction (RT-PCR) was performed using primers designed to amplify a 562-bp PVX fragment, and the resultant bands were quantified using ImageGauge software. As an internal control, two housekeeping genes, actin and elongation factor $1 \mathrm{a}(\mathrm{Ef}-1 \mathrm{a})$, from $N$. benthamiana were also amplified (Supplementary Fig. S3). No increase in PVX genomic RNA accumulation with respect to the control sample was detected in any experiment. Amplification with specific primers flanking the PVX vector cloning site next to the duplicated $\mathrm{CP}$ promoter into which geminiviral sequences were cloned (Cañizares et al. 2008) was used to confirm their integrity in the recombinant viruses. All of the recombinant viruses except the one containing $C 4$ from TYLCMalV retained their geminiviral sequences.

Plants infected with recombinant PVX vectors were monitored under UV light at $8,16,26,40$, and 60 dpi to evaluate

Table 1. Summary of the symptoms caused by geminiviral proteins C2, C4, and V2 expressed from Potato virus X (PVX) at 16 days post infection ${ }^{\text {a }}$

\begin{tabular}{|c|c|c|c|c|c|c|}
\hline Protein & TYLCSV & TYLVC & TYLCV-Mld & TYLC-MalV & PVX & NSs \\
\hline \multicolumn{7}{|l|}{ Local } \\
\hline $\mathrm{C2}$ & $\mathrm{N}$ & $\mathrm{Y}$ & $\mathrm{Y}$ & $\mathrm{Y}$ & $\mathrm{Y}$ & $\mathrm{N}$ \\
\hline C4 & $\mathrm{Y}$ & $\mathrm{Y}$ & $\mathrm{Y}$ & $\mathrm{Y}$ & $\mathrm{Y}$ & $\mathrm{N}$ \\
\hline V2 & $\mathrm{N}$ & $\mathrm{N}$ & $\mathrm{N}$ & $\mathrm{N}$ & $\mathrm{Y}$ & $\mathrm{N}$ \\
\hline \multicolumn{7}{|c|}{ Systemic } \\
\hline C2 & $\mathrm{N}$ & $\mathrm{C}$ & $\mathrm{C}$ & $\mathrm{C}+$ & $\mathrm{C}$ & $\mathrm{N}$ \\
\hline C4 & $\mathrm{C}+$ & $\mathrm{C}+$ & $\mathrm{C}+$ & $\mathrm{C}$ & $\mathrm{C}$ & $\mathrm{N}$ \\
\hline V2 & $\mathrm{N}$ & $\mathrm{N}$ & $\mathrm{N}$ & $\mathrm{N}$ & $\mathrm{C}$ & $\mathrm{N}$ \\
\hline
\end{tabular}

${ }^{\text {a }}$ Viral open reading frames were expressed from a PVX vector and tested individually in 16c Nicotiana benthamiana leaves co-infiltrated with a 35S-green fluorescent protein (GFP)-expressing Agrobacterium tumefaciens culture. Co-agroinoculation of 35S-GFP with either the empty PVX vector (PVX) or a recombinant PVX virus expressing a gene-silencing suppressor from Tomato spotted wilt virus, the nonstructural protein (NSs), were used as negative and positive controls, respectively. Local symptoms: yellowing (Y) or a necrosis (N) of the agroinfiltrated area. Systemic symptoms: mild symptoms typical of a PVX infection, including mild vein yellowing, very mild vein thickening and a faint mosaic (C), enhanced PVX symptoms (C+), or systemic necrosis (N). Viruses: Tomato yellow leaf curl Sardinia virus (TYLCSV), Tomato yellow leaf curl virus (TYLCV), TYLCV-mild (Mld), and Tomato yellow leaf curl Malaga virus (TYLCMalV). 
the spread of systemic silencing. An arbitrary silencing index was established to visually categorize plants between six levels of systemic silencing, from 0 (plant with no silenced leaves) to 5 (plant with all of its leaves silenced) (Fig. 5A). Values according to this index were assigned to individual plants, and the mean results per experiment on each observation day are represented graphically (Fig. 5B). Although expression of $\mathrm{C} 2$ from TYLCV, TYLCV-Mld, and TYLCMalV did not block systemic silencing, their expression did delay its spread compared with the plants infected with the empty PVX vector. A slight delay in the spread of gene silencing at the early stages of the infection (16 and $26 \mathrm{dpi}$ ) was also observed in plants infected with PVX C4-expressing vectors, except for the one encoded by TYLCMalV.

\section{Analysis of gene-silencing-suppressor activity in other host plants.}

Traditionally, transient assays used to determine whether a protein functions as a gene-silencing suppressor have been carried out in $N$. benthamiana plants. Although these in vivo assays are very useful for determining suppression activity, it is uncertain whether proteins capable of suppressing gene silencing in this model plant will retain the same activity in other hosts. To determine whether the TYLCD viral proteins function as silencing suppressors in tomato, we established the conditions necessary to carry out a two-component Agrobacterium infiltration assay in tomato leaves, similar to the one commonly used in $N$. benthamiana. As a gene marker, we selected DsRed (red fluorescent protein, Clontech, Palo Alto, CA, U.S.A.), because GFP fluorescence cannot be visualized in tomato leaves. The two most representative species of the TYLCD cluster present in Spain were selected to carry out this analysis, because they differ in the severity and type of symptoms produced in tomato as well as in their host range. TYLCV but not TYLCSV is able to infect bean and pepper (Monci et al. 2002; Morilla et al. 2005; Navas-Castillo et al. 1997). S. lycopersicum 'Moneymaker' leaves were co-infiltrated with two A. tumefaciens cultures expressing DsRed and the desired viral coding sequences under the control of the $35 \mathrm{~S} \mathrm{CaMV}$ promoter. Co-infiltration of $35 \mathrm{~S}$ DsRed with either the empty binary vector or a plasmid expressing P19 was used as negative and positive controls, respectively. Leaf patches infiltrated with 35S-DsRed plus P19 displayed stronger levels of red fluorescence than leaves agroinfiltrated with DsRed and the empty vector (Fig. 6A). This increase in fluorescence correlated with a rise in the amount of DsRed protein accumulated in leaf tissues where P19 is expressed, confirming that P19 also functions as a gene-silencing suppressor in tomato (Fig. 6B; quantified in Supplementary Fig. S4A). Expression of $\mathrm{C} 2$ and $\mathrm{V} 2$ from both geminiviruses also produced a remarkable increase in fluorescence and in the level of DsRed protein accumulation. In contrast, $\mathrm{C} 4$ caused little or no increase in fluorescence or DsRed protein accumulation (Fig. 6). The expression of viral genes in the agroinfiltrated tissues was confirmed by RT-PCR using specific primers and tomato EF-1a as an internal control (Supplementary Fig. S5).

To test the suppressor activity of the viral proteins in a nonshared natural host, we devised an assay using common bean 'Bush-Plaja'. Because no previous information was available regarding its sensitivity to TYLCV or TYLCSV infection, we first determined whether these viruses were able to systemically infect this bean cultivar. Plants infected with TYLCV developed the symptoms typically associated with Bean crumple leaf disease, whereas plants inoculated with TYLCSV remained asymptomatic. Analysis of total DNA extracted from the apex of inoculated plants confirmed the presence of viral DNA only for plants inoculated with TYLCV but not for plants inoculated with TYLCSV (Supplementary Fig. S6, lower panel).
Silencing-suppression assays in common bean leaves were carried out in a similar manner to those in tomato. Agroinfiltration of bean leaves with 35S-DsRed plus 35S-P19 confirmed that, as in tomato, P19 increased red fluorescence and DsRed protein accumulation, indicating that P19 can also suppress silencing in bean (Fig. 7). Only co-infiltration of TYLCV V2 produced an increase similar to P19 in terms of red fluorescence and protein accumulation (Fig. 7). Fluorescence induced by TYLCV C4 expression, although slightly more intense than that observed in tissues agroinfiltrated with the empty vector, was clearly milder than that induced by V2 (Fig. 7A). Similarly, DsRed protein levels were only moderately increased (Fig. 7B). Interestingly, none of the TYLCSV gene-silencing suppressors were able to restore red fluorescence or DsRed protein accumulation in the agroinfiltrated patches. The expression of the different viral genes in agroinfiltrated tissues was confirmed by RT-PCR using viral ORF-specific primers and bean ubiquitin as an internal control (Supplementary Fig. S7). Taken together,
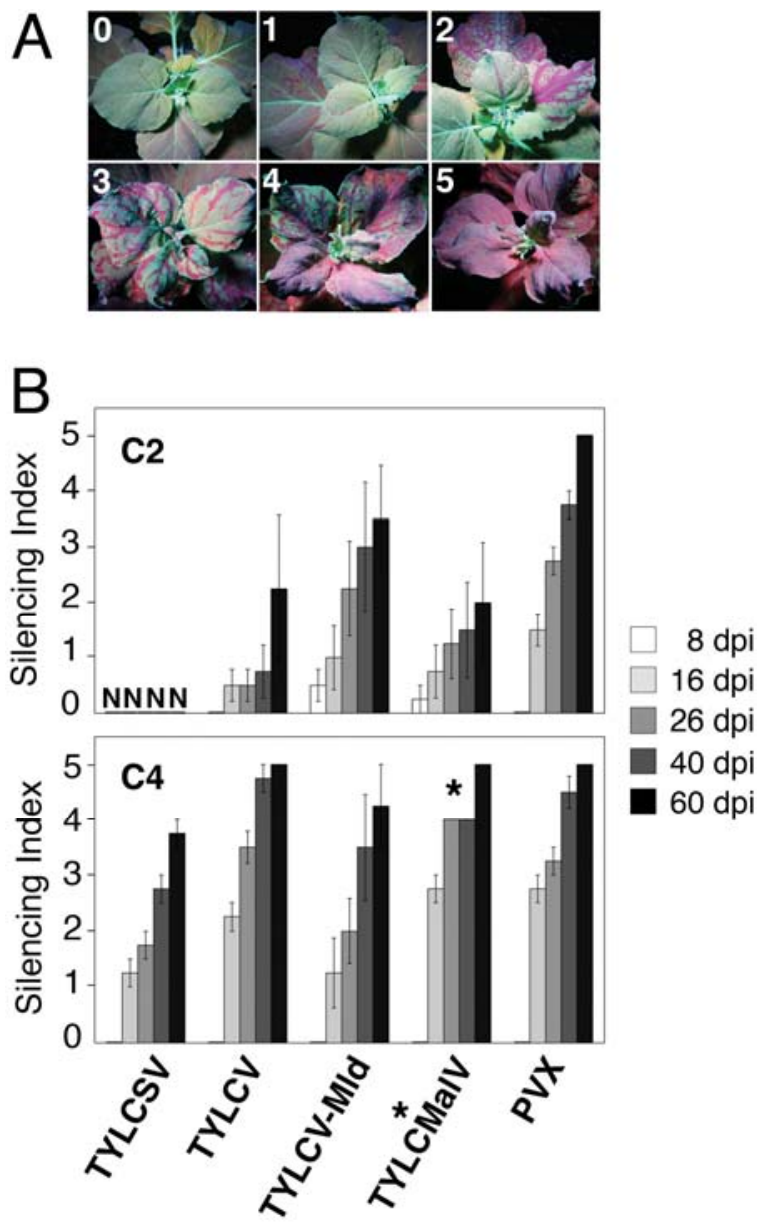

Fig. 5. Suppression of green fluorescent protein (GFP) systemic silencing by Potato virus $X$ (PVX) expression of $\mathrm{C} 2$ or $\mathrm{C} 4$ proteins in 16c Nicotiana benthamiana plants. Plants were infiltrated with two different Agrobacterium tumefaciens cultures expressing GFP and a geminiviral protein from PVX. A, Pictures under UV represent levels of systemic silencing (silencing index) from 0 (no silenced leaves) to 5 (plant with all the leaves silenced). B, Systemic silencing of plants agroinfiltrated with recombinant PVX expressing C2 or C4 proteins from Tomato yellow leaf curl Sardinia virus (TYLCSV), Tomato yellow leaf curl virus (TYLCV), TYLCV-mild (Mld), or Tomato yellow leaf curl Malaga virus (TYLCMalV) at 8, 16, 26, 40 , and 60 days postinfiltration (dpi). Values correspond to the average of four plants. Plants infected with nonrecombinant PVX viruses were used as control. Bars represent standard deviation. Plants inoculated with PVX expressing C2 from TYLCSV showed systemic necrosis (N); * indicates that this result corresponds to a clone that has lost the geminiviral sequence. 
our results suggest that V2 and C4 viral proteins from TYLCV can act as strong and weak local silencing suppressors in bean, respectively, whereas none of the TYLCSV viral proteins seem to have a significant effect on local silencing in the same host.

\section{$\mathrm{C} 4$ but not $\mathrm{C} 2$ or $\mathrm{V} 2$ expression alter}

Arabidopsis development and growth.

In order to determine the effect of TYLCD-associated viral silencing suppression on plant growth and development and complete our analysis of C2, C4, and V2 TYLCD proteins, transgenic Arabidopsis thaliana Col-0 plants were generated with the same constructs used for the gene-silencing assays. None of the plant lines expressing C2 or V2 (8 to 10 independent transgenic lines) exhibited any detectable effect on normal growth or development (data not shown). However, expression of C4 from TYLCSV, TYLCV, and TYLCMalV produced severe developmental abnormalities, including stunting, rolling, downward curling, and reduction in leaf size, whereas signifi-
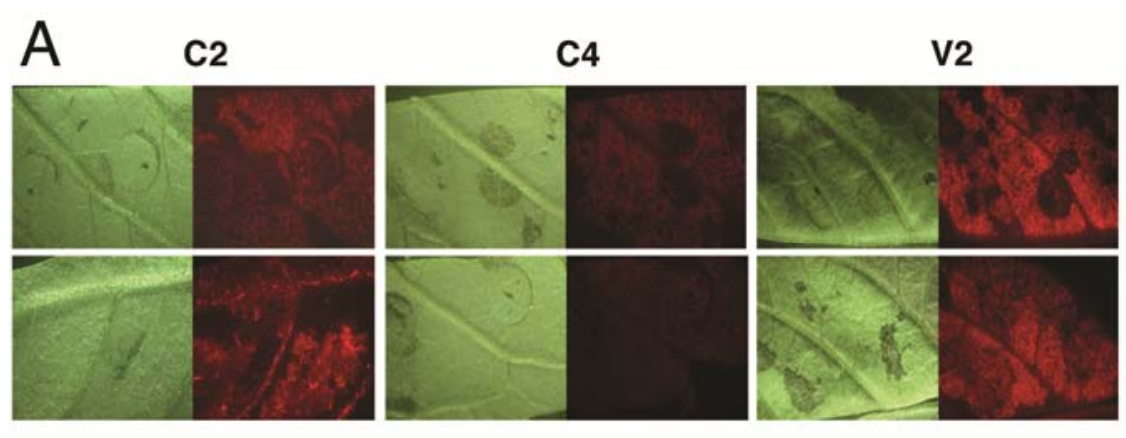

TYLCSV

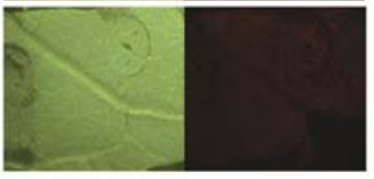

TYLCV
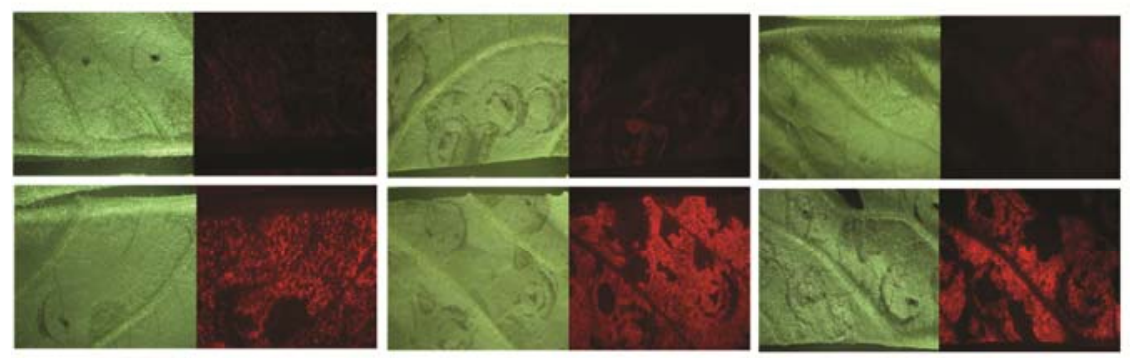

C-

P19

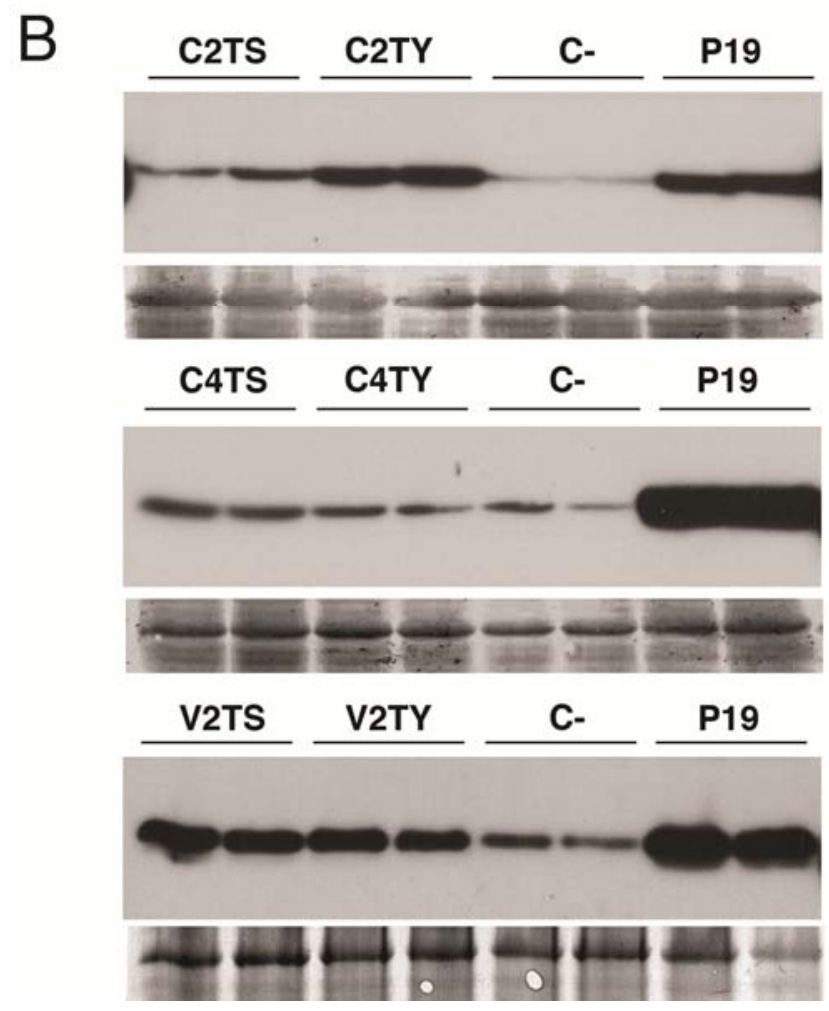

\section{DsRed}

Total protein

DsRed

\section{Total protein}

\section{DsRed}

\section{Total protein}

Fig. 6. Local post-transcriptional gene silencing suppression in tomato plants. A, Leaf patches of tomato plants infiltrated with a mixture of two different Agrobacterium tumefaciens cultures expressing DsRed and C2, C4, and V2 from Tomato yellow leaf curl Sardinia virus (TYLCSV) (TS) or Tomato yellow leaf curl virus (TYLCV) (TY) were photographed under UV light at 7 days postinfiltration (dpi). P19 and the empty vector (C-) were used as positive and negative controls, respectively. B, Sodium dodecyl sulfate polyacrylamide gel electrophoresis and immunoblot analysis of infiltrated tissues at 7 dpi with anti-DsRed antibody. Coomassie blue staining of the protein blot is shown as loading control. Each lane was loaded with $20 \mu \mathrm{g}$ of total protein obtained from two independent extractions. 
cantly milder defects were observed in the plants expressing C4 from TYLC-Mld (Fig. 8).

\section{DISCUSSION}

The epidemiology and evolution of TYLCD in Spain has been extensively analyzed since its first description in 1993 (Díaz-Pendón et al. 2010). The disease is caused by a cluster of viruses, which originated by the successive introduction of
TYLCSV, TYLCV, and TYLCV-Mld. Because mixed infections, recombination, and synergism occur among these viruses and variations in their host specificity and transmission has been described, this viral complex can be considered an exceptional system to analyze the connection between these biological characteristics and the gene-silencing-suppression activities of their proteins.

The data obtained in this work (Table 2) show that V2 proteins from all the TYLCD viruses are the strongest suppressors
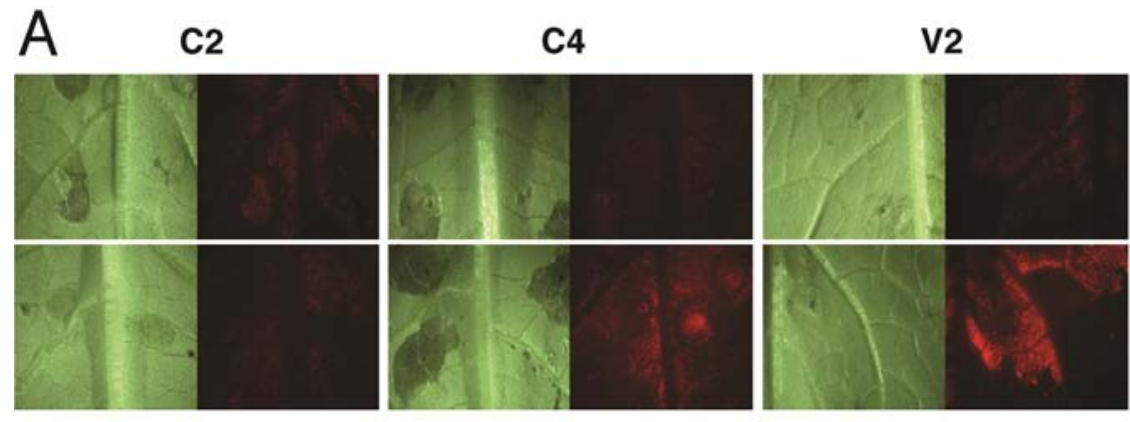

TYLCSV
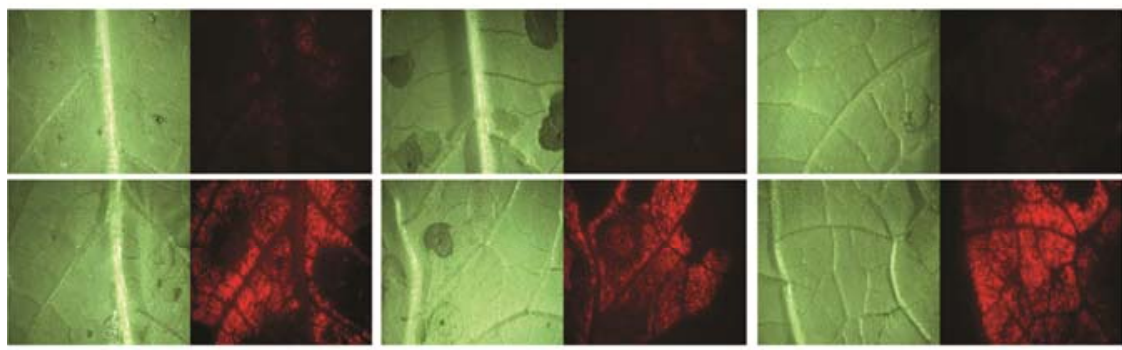

C-
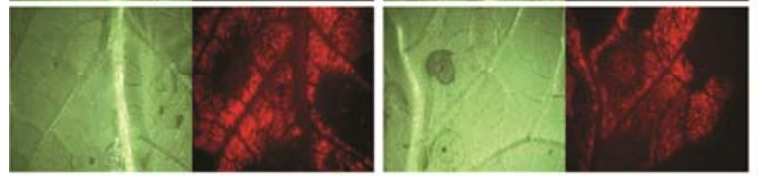

P19

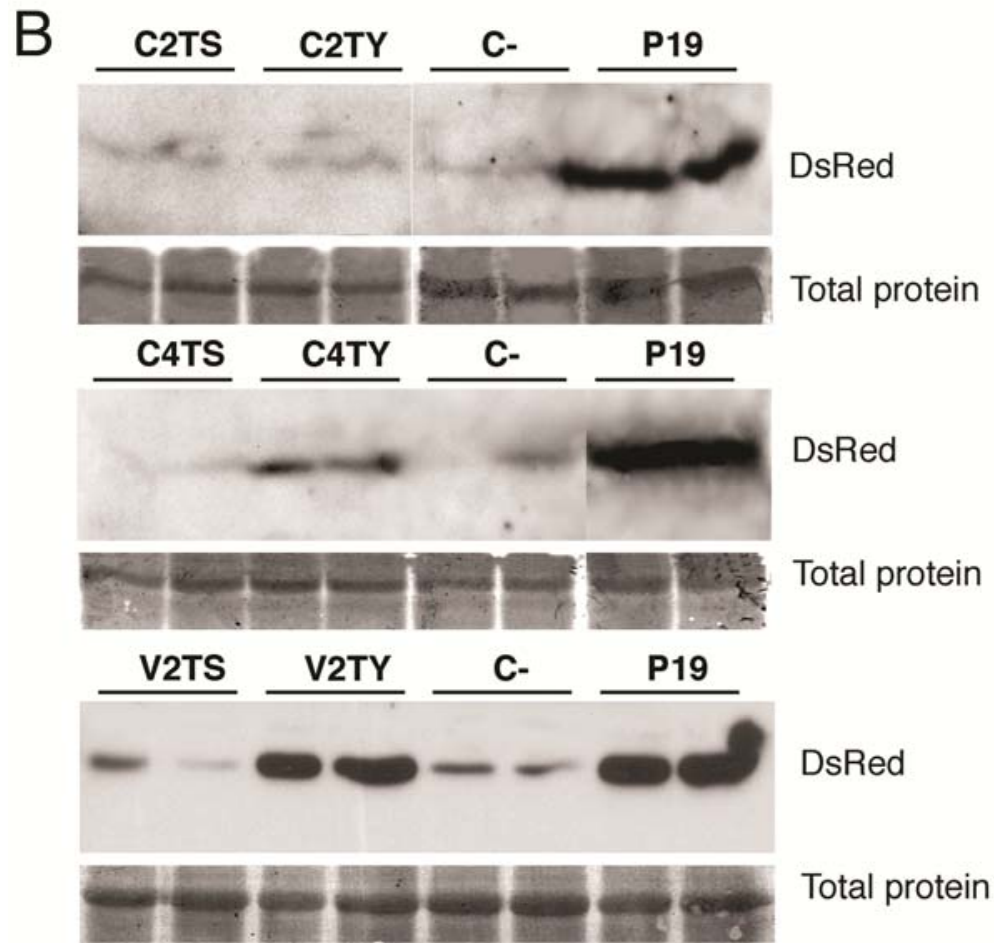

Fig. 7. Local post-transcriptional gene silencing suppression in common bean plants. A, Leaf patches of common bean plants infiltrated with a mixture of two different Agrobacterium tumefaciens cultures expressing DsRed and C2, C4, and V2 from Tomato yellow leaf curl Sardinia virus (TYLCSV) (TS) or Tomato yellow leaf curl virus (TYLCV) (TY) were photographed under UV light at 9 days postinfiltration (dpi). P19 and the empty vector (C-) were used as positive and negative controls, respectively. B, Sodium dodecyl sulfate polyacrylamide gel electrophoresis and immunoblot analysis of infiltrated tissues at $9 \mathrm{dpi}$ with anti-DsRed antibody. Coomassie blue staining of the protein blot is shown as loading control. Each lane was loaded with $20 \mu \mathrm{g}$ of total protein obtained from two independent extractions. 
of local silencing in $N$. benthamiana, while $\mathrm{C} 2$ and $\mathrm{C} 4$ behaved as weaker or null PTGS suppressors (Fig. 2). Thus, despite the viruses used here being closely related and, consequently, showing high protein sequence homology (Supplementary Fig. S8), their limited amino acid differences clearly have important biological consequences. Phylogenetic analyses are broadly consistent with the results of local silencing-suppression assays. Interestingly, C4 proteins from TYLCV-Mld and TYLCMalV that differ in only one amino acid at position 47 showed some variation in local PTGS suppression. Although we did not detect variations in $\mathrm{C} 4 \mathrm{mRNA}$ accumulation that would explain this difference, we cannot exclude the possibility that variations in protein accumulation could account for their differing suppression activity.

It is noteworthy that, for most of the studied viruses, with the exception of TYLCMalV, only two of the three analyzed proteins could suppress silencing in the local $N$. benthamiana assays. Interestingly, our results point toward an inverse correlation for the suppression activities of $\mathrm{C} 2$ and $\mathrm{C} 4$. Viruses with $\mathrm{C} 4$ proteins possessing significant suppression activity (TYLCSV and TYLCV) encode C2 proteins that are unable to suppress local silencing. Conversely, those producing active C2 proteins (TYLCV-Mld and TYLCMalV) possess C4 proteins with little or no effect on GFP silencing. These results suggest that the existence of successful TYLCD viruses require two types of RNA-silencing suppressors with strong (V2) and weaker (C2 or $\mathrm{C} 4)$ activities. Although a partial overlap of $\mathrm{C} 2$ and $\mathrm{C} 4$ function could be inferred from these results, previous data clearly indicate that $\mathrm{C} 2$ and $\mathrm{C} 4$ affect, at least partially, different silencing pathways. Synergy between closely related viruses that differ in the suppressor activity of $\mathrm{C} 2$ and $\mathrm{C} 4$, such as ACMV and EACMV (Vanitharani et al. 2004, 2005) or TYLCSV and TYLCV-Mld (Morilla et al. 2005), could be explained as a result of an additive effect of silencing suppression of both sets of viral proteins. The different subcellular localization patterns of these proteins- $\mathrm{C} 2$ is nuclear (Dong et al. 2003; Van Wezel et al. 2001) whereas C4 is cytoplasmic and nuclear (Dogra et al. 2009; Piroux et al. 2007) —and the differences in the molecular suppression mechanism described up to now (Raja et al. 2010) further support a functional separation of $\mathrm{C} 2$ and $\mathrm{C} 4$ activities.

It is remarkable that TYLCMalV is the only virus encoding three proteins that can suppress silencing. The biological properties of TYLCMalV, a natural recombinant between TYLCSV and TYLCV-Mld, suggest that its maintenance and spread in the population could be due to this being better adapted than either parental virus (García-Andrés et al. 2007a and b). A more efficient silencing-suppression mechanism could be one factor involved in this improved adaptation.

In spite of the fact that none of the viral proteins seem to be able to avoid the spread of the silencing signal out of the infiltrated area (Fig. 3B), most of them produce a delay that disappears almost completely at $30 \mathrm{dpi}$ (Fig. 3C). Overexpression of the viral protein in all of the tissues of the plant using PVX vectors confirm this results for $\mathrm{C} 4$ (at early stages of infection) and C2 from TYLCV, TYLCV-Mld, and TYLCMalV (Fig. 5). Unfortunately, no conclusions could be inferred for TYLCSV $\mathrm{C} 2$ or any of the V2 proteins, because their PVX-mediated ex-
Col-0

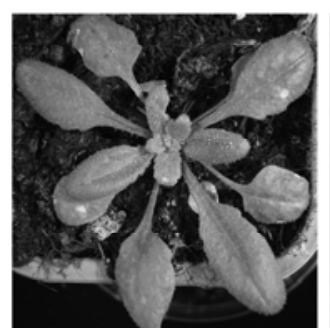

TYLCSV

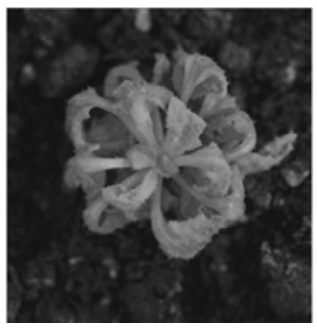

TYLCV

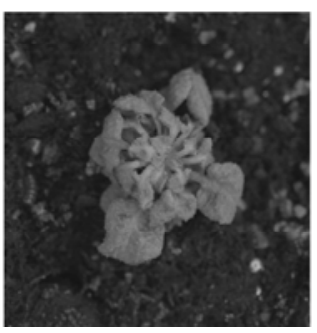

TYLCV-MId

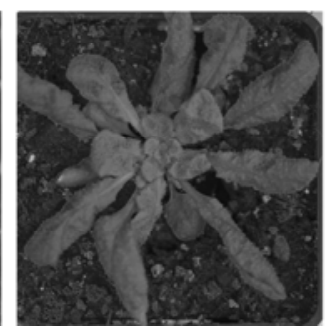

TYLCMaIV

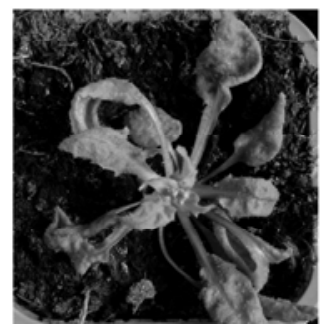

Fig. 8. Transgenic Arabidopsis thaliana plants expressing C4 from Tomato yellow leaf curl disease (TYLCD) viruses. Pictures correspond to representative 3-week-old nontransgenic (Col-0) or transgenic plants expressing C4 from TYLCD viruses: Tomato yellow leaf curl Sardinia virus (TYLCSV), Tomato yellow leaf curl virus (TYLCV), TYLCV-mild (Mld), and Tomato yellow leaf curl Malaga virus (TYLCMalV).

Table 2. Summary of the results obtained from agroinfiltration assays in the different hosts for C2, C4, and V2 from Tomato yellow leaf curl disease viruses ${ }^{\text {a }}$

\begin{tabular}{|c|c|c|c|c|c|c|}
\hline \multirow[b]{2}{*}{ Virus, gene } & \multicolumn{4}{|c|}{ Nicotiana benthamiana } & \multirow{2}{*}{$\begin{array}{c}\text { Tomato } \\
\text { Local }\end{array}$} & \multirow{2}{*}{$\begin{array}{l}\text { Bean } \\
\text { Local }\end{array}$} \\
\hline & Local & Non-cell autonomous & Systemic from $35 \mathrm{~S}$ & Systemic from PVX & & \\
\hline \multicolumn{7}{|l|}{ TYLCSV } \\
\hline$C 2$ & No & No & Delay & $\mathrm{nd}^{*}$ & Yes & No \\
\hline$C 4$ & Yes & No & Delay & Delay & No & No \\
\hline$V 2$ & Yes & No & Delay & $\mathrm{nd}^{*}$ & Yes & No \\
\hline \multicolumn{7}{|l|}{ TYLCV } \\
\hline$C 2$ & No & No & Delay & Delay & Yes & No \\
\hline$C 4$ & Yes & No & Delay & Delay & No & Yes \\
\hline$V 2$ & Yes & No & Delay & nd* & Yes & Yes \\
\hline \multicolumn{7}{|l|}{ TYLCV-Mld } \\
\hline$C 2$ & Yes & No & Delay & Delay & nd & nd \\
\hline$C 4$ & No & No & Delay & Delay & nd & nd \\
\hline$V 2$ & Yes & No & Delay & nd* & nd & nd \\
\hline \multicolumn{7}{|l|}{ TYLCMalV } \\
\hline$C 2$ & Yes & No & Delay & Delay & nd & nd \\
\hline C4 & Yes & No & Delay & nd & nd & nd \\
\hline$V 2$ & Yes & No & Delay & nd* & nd & nd \\
\hline
\end{tabular}

a Viruses: Potato virus X (PVX), Tomato yellow leaf curl Sardinia virus (TYLCSV), Tomato yellow leaf curl virus (TYLCV), TYLCV-mild (Mld), and Tomato yellow leaf curl Malaga virus (TYLCMalV). Yes = the viral protein suppressed RNA silencing in this assay; No = the viral protein did not suppress RNA silencing in this assay; nd $=$ not determined; Delay $=$ the viral protein did not suppress silencing but produced a delay in the process; and $*=$ the viral protein produced necrosis and death of the agroinfiltrated plant. 
pression induced systemic necrosis before silencing was obvious in the control plants infected with PVX.

The effects of viral protein overexpression on the plant phenotype is a useful tool to determine whether suppressors share silencing pathways and allows us to uncover additional functions of the viral proteins. Although all the suppressors analyzed here inhibited silencing, only $\mathrm{C} 4$ induced developmental defects that resemble the symptoms produced during viral infection (Fig. 8). All C4 proteins expressed as transgenes in $A$. thaliana or from PVX in $N$. benthamiana produced developmental abnormalities, including a reduction in leaf size and downward leaf curling and rolling. The total absence of effect on symptom production of the PVX recombinant virus containing C4 from TYLCMalV (Fig. 4; Table 1) might be caused by the loss of the geminiviral sequence detected in the RT-PCR. Curiously, the milder effect observed when C4 of TYLCMalV and, particularly, of TYLCV-Mld were expressed in transgenic plants correlated with reduced local silencing-suppression activity and weaker symptoms induced in tomato or $N$. benthamiana compared with TYLCV (Monci et al. 2002; Morilla et al. 2005), suggesting a connection between silencing suppression and symptom development. Expression of viral proteins using the PVX-based system also allows identification of pathogenicity determinants that cause new phenotypes not associated with the native viral infection. An example of this effect was observed by the induction of necrotic lesions similar to those produced during the HR at local and systemic levels in plants infected with a recombinant PVX virus expressing $\mathrm{C} 2$ from TYLCSV or any of the V2 proteins (Fig. 4; Table 1). This suggests that these proteins are avirulence factors that interact with the product of a resistance gene to trigger a response defense involving an HR, as has been previously reported for V2 and $\mathrm{C} 2$ from several Begomovirus spp. that also induced necrosis in N. benthamiana when expressed from a PVX vector (Amin et al. 2011; Chowda-Reddy et al. 2008; Mubin et al. 2010; Sharma and Ikegami 2010; Sharma et al. 2010; Zhang et al. 2012). The absence of HR induction in the $A$. thaliana transgenic plants expressing viral proteins points to a virus or host variability in the recognition of Begomovirus $\mathrm{C} 2$ or $\mathrm{V} 2$ as avirulence factors.

Since the first description of a viral silencing suppressor, the activities of a large number of proteins from RNA and DNA viruses have been tested using transient assays in $N$. benthamiana. Although these studies are very informative, they can potentially mask a host-dependent variability of the suppressor activity. To overcome these restraints, we have devised patch assays for two important crop hosts of TYLCD viruses: tomato and bean. The data shown here demonstrate, for the first time, that P19, one of the strongest silencing suppressors known, is also capable of functioning as a suppressor in tomato and bean, thus extending the biotechnological utility of this viral protein to improve the efficiency of crops as biofactories. Our analysis of C2, C4, and V2 from TYLCSV and TYLCV species in $N$. benthamiana, tomato, and bean demonstrates that their silencing-suppressor activity in plants is host dependent, confirming the data obtained in protoplasts using the suppressor $2 \mathrm{~b}$ from Cucumber mosaic virus $Y$ (Shimura et al. 2008). Although V2 from both viruses function as suppressors in tomato as well as in $N$. benthamiana, V2 from TYLCSV is unable to maintain DsRed expression level in bean. Moreover, TYLCV C2, which behaves as a weak silencing suppressor in $N$. benthamiana and a strong suppressor in tomato, is unable to suppress silencing in bean. Previous data on the mechanism of action of V2 and C2 indicate that its activity as a PTGS suppressor relies heavily on interactions with host proteins (Raja et al. 2010). Thus, the host specificity of V2 and C2 could be explained by differences in the ability of these proteins to interact with their corresponding host factors. The variations in the silencing activity of $\mathrm{C} 4$ in bean and tomato are more difficult to explain because the suppression mechanism proposed for C4 relies on its ability to bind ssRNA (Chellappan et al. 2005). Interestingly, while two TYLCV proteins showed silencing-suppression activity in tomato (V2 and C2) and bean (V2 and C4), TYLCSV proteins only functioned as suppressors in tomato. Considering that tomato is a common host for both of the viruses, whereas bean is only infected by TYLCV, a tantalizing hypothesis is that the difference in host range could be due to their differential ability to suppress silencing in those hosts. Further experiments to confirm this hypothesis and identify the mechanism of host specificity are in progress.

\section{MATERIALS AND METHODS}

\section{Microorganisms and general methods.}

Manipulation of Escherichia coli strains were performed according to standard methods (Sambrook 2001). E. coli DH5-a was used for subcloning. All PCR-amplified fragments cloned in this work were fully sequenced. The A. tumefaciens GV3101 strain was used for the agroinfiltration assays and for transformation of Arabidopsis thaliana plants.

\section{Plasmids and cloning.}

The construction of the plasmids used in this work is summarized in Supplementary Table 1.

All full-length ORF of $C 2, C 4$, and $V 2$ from Spanish isolates of TYLCSV (accession number L27708), TYLCV (accession number AJ489258), TYLCV-Mld (accession number AF071228), and TYLCMalV (accession number AF271234) were amplified using specific primers (Supplementary Table S2) from plasmids pTYCZ40 (TYLCV) (Morilla et al. 2005), pGTYA2 (TYLCSV) (Morilla et al. 2004), p1.4ES421/99 (TYLCMalV) (Monci et al. 2002), and pSP72/97 (TYLCVMld) (Navas-Castillo et al. 1999).

A PCR fragment containing $C 2$ from TYLCSV was cloned into pSXSN1 (Sánchez-Durán et al. 2011) to yield pSXC2TS. From this plasmid, a fragment containing the $C 2$ ORF flanked by the CaMV $35 \mathrm{~S}$ promoter (35SCaMV) and Nopaline synthase terminator was subcloned into binary vector pBIN plus (Van Engelen et al. 1995) to yield pBIC2TS. A PCR fragment containing $C 2$ from TYLCMalV was cloned into pBINX to yield pBIC2TMa. PCR fragments containing $C 2$ from TYLCV and TYLCV-Mld were cloned in pBSSKII (Stratagene, La Jolla, CA, U.S.A.) to yield pC2TY and pC2TM, respectively. Restriction fragments from $\mathrm{pC} 2 \mathrm{TY}$ and $\mathrm{pC} 2 \mathrm{TM}$ containing the full ORF were subcloned into binary vector pBINX1 (Sánchez-Durán et al. 2011) to yield pBIC2TY and pBIC2TM, respectively.

PCR fragments containing C4 ORF from TYLCSV, TYLCV, TYLCV-Mld, and TYLCMalV were cloned in pBSSKII to yield pC4TS, pC4TY, pC4TM, and pC4TMa, respectively. Fragments containing the full ORF were obtained by digestion with restriction enzymes and subcloned into binary vector $\mathrm{pBINX} 1$ to yield pBIC4TS, pBIC4TY, pBIC4TM, and pBIC4TMa, respectively.

PCR fragments containing V2 ORF from TYLCSV, TYLCV, TYLCV-Mld, and TYLCMalV were cloned in TOPO vector (Invitrogen, Carlsbad, CA, U.S.A.) to yield pTOPOV2TS, pTOPOV2TY, pTOPOV2TM, and pTOPOV2TMa, respectively. Fragments containing the full ORF were obtained by digestion with restriction enzymes and subcloned into binary vector $\mathrm{pBINX} 1$ to yield pBIV2TS, pBIV2TY, pBIV2TM, and pBIV2TMa, respectively.

To generate the PVX expression vectors, PCR-amplified fragments containing $C 2$ from TYLCSV and TYLCMalV, and 
C4 from TYLCV-Mld were subcloned in a pGEMT-easy vector (Promega Corp., Madison, WI, U.S.A.) to yield pGEM-C2TS, pGEM-C2TMa, and pGEM-C4TM, respectively. Restriction fragments from those plasmids containing the ORF were cloned into PGR107 (Jones et al. 1999), yielding the corresponding PVX expression vectors: PVX-C2TS, PVX-C2TMa, and PVXC4TM. Restriction fragments containing the rest of the viral ORF were cloned into PGR107 to yield the other PVX expression vectors for TYLCSV (PVX-C4TS and PVX-V2TS), TYLCV (PVX-C2TY, PVX-C4TY, and PVX-V2TY), TYLCVMld (PVX-C2TM and PVX-V2TM), and TYLCVMaV (PVXC4TMa and PVX-V2TMa).

\section{Agroinfiltration and infection assays.}

Plant leaves were infiltrated with the A. tumefaciens GV3101 strain containing the corresponding plasmids. $N$. benthamiana leaves were infiltrated as described by Voinnet and associates (1998). Common bean (Bush-Plaja) and tomato (Moneymaker) leaves were agroinfiltrated at 1 or 3 to 4 weeks after germination, respectively. A. tumefaciens cultures were centrifuged and resuspended in agroinfiltration buffer (10 mM MES buffer, 10 $\mathrm{mM} \mathrm{Cl}{ }_{2} \mathrm{Mg}$, and $2.25 \mathrm{mM}$ acetosyringone). For co-infiltration, equal volumes of each $A$. tumefaciens culture (final optical density at $600 \mathrm{~nm}=0.5$ ) was used. The mixtures were kept in darkness at room temperature for $6 \mathrm{~h}$ before infiltration. Leaf discs, $10 \mathrm{~mm}$ in diameter, were punched out from infiltrated areas of leaves with a cork-borer at $4 \mathrm{dpi}$. Detection of GFP fluorescence was performed using a hand-held long-wave UV lamp (Black Ray model B, 100 AP; UV Products, Upland, CA, U.S.A.), and plants were photographed using a digital camera (Canon EOS 5D). Detection of DsRed fluorescence in leaves was performed using an epifluorescence dissecting microscope (model MZFLIII; Leica, Wetzlar, Germany) with a DsRed filter, and pictures were taken using an image capture system (model DFC 420C; Leica).

PVX infections were carried out by agroinfiltration using conditions as described above. Common bean plants were infected with TYLCSV and TYLCV by agroinoculation of plasmids pGTYA2 (Morilla et al. 2004) and pBICZ40 (Morilla et al. 2005), respectively, as previously described (Monci et al. 2005).

Plants were cultured in growth chambers at $24^{\circ} \mathrm{C}$ in long day conditions (photoperiod with $16 \mathrm{~h}$ of light and $8 \mathrm{~h}$ of darkness) before and after infiltration or infection.

\section{Analysis of nucleic acids and proteins.}

Nucleic acid manipulation was performed according to standard methods (Sambrook 2001). For the analysis of bean infection, plant DNA was extracted and subjected to PCR using specific primers for V2 of TYLCSV or TYLCV and for a ubiquitin gene of bean (TC127) (Thibivilliers et al. 2009) (Supplementary Table S3).

For RT-PCR, total RNA was isolated using Trizol reagent (Invitrogen) from agroinfiltrated leaves or from the apical leaves in the case of PVX-infected $N$. benthamiana plants. RNA was treated with RNase-free DNase I (TaKaRa, Kyoto, Japan) and subjected $(1 \mu \mathrm{g})$ to reverse transcription using SuperScript II RT reagent (Invitrogen) and oligo(dT) primers according to the manufacturer's instructions. The synthesized firststrand cDNA was then subjected to PCR amplification with PVX or geminiviral specific primers. As internal controls, mRNA from housekeeping genes was amplified using specific primers: EF-1a for tomato (accession number X53043) (Nicot et al. 2005), ubiquitin protein (TC127) for bean (Thibivilliers et al. 2009) and actin (accession number U60489), and EF-1a genes (Rotenberg et al. 2006) for $N$. benthamiana. PCR was performed with $2 \mu \mathrm{l}$ of cDNA first-strand template.
For Northern blot, total RNA from four to six agroinfiltrated leaves of $N$. benthamiana was extracted using Trizol reagent, precipitated, and redissolved in $50 \%$ formamide. Northern analyses of high and low molecular weight RNAs were performed with 10 or $15 \mu \mathrm{g}$ of total RNA. Low molecular weight RNA was separated by electrophoresis through $15 \%$ polyacrylamide-7 M urea-0.5× Tris-borate EDTA gels, transferred onto Hybond Nx filters (Amersham, Piscataway, NJ, U.S.A.) using a Hoefer TE 77 semidry transfer unit, and fixed by UV cross-linking $\left(700 \mu \mathrm{J} / \mathrm{cm}^{2}\right.$; Ultraviolet Crosslinker, Amersham). Perfect-Hyb buffer (Sigma-Aldrich, St. Louis) was used for hybridization at $42^{\circ} \mathrm{C}$ for $16 \mathrm{~h}$. High molecular weight RNA was denatured with $3.7 \%$ formaldehyde in $1 \times$ TBE and separated by electrophoresis in a $1 \%$ agarose/1× TBE gel run. Then it was transferred onto Hybond $\mathrm{Nx}$ filters (Amersham) and fixed by UV cross-linking. For Northern blots, membranes were hybridized with DNA probes (Supplementary Table S4) radiolabeled by random priming reactions (High Prime, Roche, Branchburg, NJ, U.S.A.) in the presence of $[\alpha-32 \mathrm{P}] \mathrm{dCTP}$. To confirm equal loading ethidium bromide staining of total RNA before transfer, or detection of U6, snRNA was used. The U6 snRNA probe was a complementary DNA oligonucleotide (sequence: AGGGGCCATGCTAATCTTCTC) end-labeled with $[\gamma-32 \mathrm{P}] \mathrm{ATP}$ using T4 polynucleotide kinase (New England BioLabs, Beverly, MA, U.S.A.). After hybridization, the membrane was washed once for 5 min with wash-buffer $(2 \times \mathrm{SSC}$ [ $1 \times \mathrm{SSC}$ is $0.15 \mathrm{M} \mathrm{NaCl}$ plus $0.015 \mathrm{M}$ sodium citrate] and $2 \%$ sodium dodecyl sulfate [SDS]) at room temperature, and twice for $15 \mathrm{~min}$ at $50^{\circ} \mathrm{C}$ with prewarmed wash-buffer.

All of the hybridization signals were detected by phosphorimaging using Fujix Bio-Imaging Analyzer BAS 1500 (Fuji Photo Film Co., Tokyo).

Total proteins from four to six agroinfiltrated leaves were extracted in Laemmli buffer, resolved by SDS polyacrylamide gel electrophoresis, and transferred by electroblotting onto a polyvinylidene diflouride membrane (Immobilon-P; Millipore, Bedford, MA, U.S.A.). Proteins were stained by Coomassie blue and analyzed for antibody reaction: GFP antiserum (provided by $M$. Keller, Institut de Biologie Moléculaire des Plantes) and DsRed antiserum (Living colors DsRed Polyclonal Antibody, Clontech) were used at a 1:10,000 and a 1:1000 dilution, respectively, and revealed by a second peroxidaseconjugated antibody (Biosys) through enhanced chemiluminescence (Lumi-light PLUS; Roche).

\section{Transgenic plants.}

The binary plasmids used to express $\mathrm{C} 2, \mathrm{C} 4$, and V2 from TYLCSV, TYLCV, TYLCV-Mld, and TYLCMalV from $35 \mathrm{SCaMV}$ promoter (see above) were used to obtain transgenic plants. Plasmids were mobilized into A. tumefaciens GV3101 and transformed into Arabidopsis thaliana (ecotype Col-0) using the floral dipping method (Clough and Bent 1998). Upon kanamycin selection, 6 to 10 transgenic lines per construct were established. Transgene presence was determined by PCR using viral ORF-specific primers. The number of loci was determined by kanamycin selection. Transgene expression was analyzed by semiquantitative PCR using viral ORF-specific primers (Supplementary Table S2) or by Northern blot using full-length ORF as a probe.

\section{AKNOWLEDGMENTS}

We thank M. Duarte and S. Hernández for technical assistance. This research was supported by a grant from the Spanish Ministerio de Ciencia y Tecnología (AGL2010-22287-C02-02/AGR) and Fondo Europeo de Desarrollo Regional (FEDER). A. P. Luna was awarded a Predoctoral Fellowship from the Junta de Andalucía (AGR876). 


\section{LITERATURE CITED}

Amin, I., Hussain, K., Akbergenov, R., Yadav, J. S., Qazi, J., Mansoor, S., Hohn, T., Fauquet, C. M., and Briddon, R. W. 2011. Suppressors of RNA silencing encoded by the components of the cotton leaf curl begomovirus-betasatellite complex. Mol. Plant-Microbe Interact. 24:973-983.

Bisaro, D. M. 2006. Silencing suppression by geminivirus proteins. Virology 344:158-168.

Brigneti, G., Voinnet, O., Li, W.-X., Ji, L.-H., Ding, S.-W., and Baulcombe, D. C. 1998. Viral pathogenicity determinants are suppressors of transgene silencing in Nicotiana benthamiana. EMBO (Eur. Mol. Biol. Organ.) J. 17:6739-6746.

Bucher, E., Sijen, T., de Haan, P., Goldbach, R., and Prins, M. 2003. Negative-strand tospoviruses and tenuiviruses carry a gene for a suppressor of gene silencing at analogous genomic positions. J. Virol. 77:13291336.

Cañizares, M. C., Navas-Castillo, J., and Moriones, E. 2008. Multiple suppressors of RNA silencing encoded by both genomic RNAs of the crinivirus, Tomato chlorosis virus. Virology 379:168-174.

Chellappan, P., Vanitharani, R., and Fauquet, C. M. 2005. MicroRNAbinding viral protein interferes with Arabidopsis development. Proc. Natl. Acad. Sci. U.S.A. 102:10381-10386.

Chowda-Reddy, R. V., Achenjang, F., Felton, C., Etarock, M. T., Anangfac, M. T., Nugent, P., and Fondong, V. N. 2008. Role of a geminivirus AV2 protein putative protein kinase $\mathrm{C}$ motif on subcellular localization and pathogenicity. Virus Res. 135:115-124.

Clough, S. J., and Bent, A. F. 1998. Floral dip: a simplified method for Agrobacterium-mediated transformation of Arabidopsis thaliana. Plant J. 16:735-743.

Cohen, S., and Antignus, Y. 1994. Tomato yellow leaf curl virus (TYLCV), a whitefly-borne geminivirus of tomatoes. Adv. Dis. Vector Res. 10:259-288.

Cohen, S., and Nitzany, F. 1966. Transmission and host range of the Tomato yellow leaf curl virus. Phytopathology 56:1127-1131.

Díaz-Pendón, J. A., and Ding, S.-W. 2008. Direct and indirect roles of viral suppressors of RNA silencing in pathogenesis. Annu. Rev. Phytopathol. 46:303-326.

Díaz-Pendón, J. A., Cañizares, M. C., Moriones, E., Bejarano, E. R., Czosnek, H., and Navas-Castillo, J. 2010. Tomato yellow leaf curl viruses: ménage à trois between the virus complex, the plant and the whitefly vector. Mol. Plant Pathol. 11:441-450.

Ding, S.-W. 2010. RNA-based antiviral immunity. Nat. Rev. Immunol. 10:632-644

Dogra, S. C., Eini, O., Rezaian, M. A., and Randles, J. W. 2009. A novel shaggy-like kinase interacts with the Tomato leaf curl virus pathogenicity determinant $\mathrm{C} 4$ protein. Plant. Mol. Biol. 71:25-38.

Dong, X., Van Wezel, R., Stanley, J., and Hong, Y. 2003. Functional characterization of the nuclear localization signal for a suppressor of posttranscriptional gene silencing. J. Virol. 77:7026-7033.

Fauquet, C. M., Briddon, R. W., Brown, J. K., Moriones, E., Stanley, J., Zerbini, M., and Zhou, X. 2008. Geminivirus strain demarcation and nomenclature. Arch. Virol. 153:783-821.

Fukunaga, R., and Doudna, J. 2009. dsRNA with 5' overhangs contributes to endogenous and antiviral RNA silencing pathways in plants. EMBO (Eur. Mol. Biol. Organ.) J. 28:545-555.

García-Andrés, S., Accotto, G. P., Navas-Castillo, J., and Moriones, E. 2007a. Founder effect, plant host, and recombination shape the emergent population of begomoviruses that cause the tomato yellow leaf curl disease in the Mediterranean basin. Virology 359:302-312.

García-Andrés, S., Tomás, D. M., Sánchez-Campos, S., Navas-Castillo, J., and Moriones, E. 2007b. Frequent occurrence of recombinants in mixed infections of tomato yellow leaf curl disease-associated begomoviruses. Virology 365:210-219.

Glick, E., Zrachya, A., Levy, Y., Mett, A., Gidoni, D., Belausov, E., Citovsky, V., and Gafni, Y. 2008. Interaction with host SGS3 is required for suppression of RNA silencing by Tomato yellow leaf curl virus V2 protein. Proc. Natl. Acad. Sci. U.S.A. 105:157-161.

Gopal, P., Pravin Kumar, P., Sinilal, B., Jose, J., Kasin Yadunandam, A., and Usha, R. 2007. Differential roles of $\mathrm{C} 4$ and betaC1 in mediating suppression of post-transcriptional gene silencing: evidence for transactivation by the $\mathrm{C} 2$ of Bhendi yellow vein mosaic virus, a monopartite begomovirus. Virus Res. 123:9-18.

Hamilton, A. J., and Baulcombe, D. C. 1999. A species of small antisense RNA in posttranscriptional gene silencing in plants. Science 286:950-952.

Hamilton, A., Voinnet, O., Chappell, L., and Baulcombe, D. 2002. Two classes of short interfering RNA in RNA silencing. EMBO (Eur. Mol. Biol. Organ.) J. 21:4671-4679.

Hanley-Bowdoin, L., Settlage, S. B., Orozco, B. M., Nagar, S., and Robertson, D. 2000. Geminiviruses: models for plant DNA replication, transcription, and cell cycle regulation. Crit. Rev. Biochem. Mol. Biol. 35:105-140.

Haseloff, J., Siemering, K. R., Prasher, D. C., and Hodge, S. 1997. Removal of a cryptic intron and subcellular localization of green fluorescent protein are required to mark transgenic Arabidopsis plants brightly. Proc. Natl. Acad. Sci. U.S.A. 94:2122-2127.

Himber, C., Dunoyer, P., Moissiard, G., Ritzenthaler, C., and Voinnet, O. 2003. Transitivity-dependent and -independent cell-to-cell movement of RNA silencing. EMBO (Eur. Mol. Biol. Organ.) J. 22:4523-4533.

Jones, L., Hamilton, A. J., Voinnet, O., Thomas, C. L., Maule, A. J., and Baulcombe, D. C. 1999. RNA-DNA interactions and DNA methylation in post-transcriptional gene silencing. Plant Cell 11:2291-2302.

Llave, C. 2010. Virus-derived small interfering RNAs at the core of plantvirus interactions. Trends Plant Sci. 15:701-707.

Llave, C., Kasschau, K. D., and Carrington, J. C. 2000. Virus-encoded suppressor of posttranscriptional gene silencing targets a maintenance step in the silencing pathway. Proc. Natl. Acad. Sci. U.S.A. 97:1340113406.

Monci, F., Sánchez-Campos, S., Navas-Castillo, J., and Moriones, E. 2002. A natural recombinant between the geminiviruses Tomato yellow leaf curl Sardinia virus and Tomato yellow leaf curl virus exhibit a novel pathogenic phenotype and is becoming prevalent in Spanish populations. Virology 303:317-326.

Monci, F., García-Andrés, S., Maldonado, J. A., and Moriones, E. 2005. Resistance to monopartite begomoviruses associated with the bean leaf crumple disease in Phaseolus vulgaris controlled by a single dominant gene. Phytopathology 95:819-826.

Morilla, G., Antúnez, C., Bejarano, E. R., Janssen, D., and Cuadrado, I. M. 2003. A new Tomato yellow leaf curl virus strain in southern Spain. Plant Dis. 87:1004-1004.

Morilla, G., Krenz, B., Jeske, H., Bejarano, E. R., and Wege, C. 2004. Tête à tête of Tomato yellow leaf curl virus and Tomato yellow leaf curl Sardinia virus in single nuclei. J. Virol. 78:10715-10723.

Morilla, G., Janssen, D., García-Andrés, S., Moriones, E., Cuadrado, I. M., and Bejarano, E. R. 2005. Pepper (Capsicum annuum) is a dead-end host for Tomato yellow leaf curl virus. Phytopathology 95:1089-1097.

Mubin, M., Amin, I., Amrao, L., Briddon, R. W., and Mansoor, S. 2010. The hypersensitive response induced by the V2 protein of a monopartite begomovirus is countered by the C2 protein. Mol. Plant Pathol. 11:245254.

Navas-Castillo, J., Sánchez-Campos, S., Díaz, J. A., Sáez-Alonso, E., and Moriones, E. 1997. First report of Tomato yellow leaf curl virus-Is in Spain: coexistence of two different geminiviruses in the same epidemic outbreak. Plant Dis. 81:1461

Navas-Castillo, J., Sánchez-Campos, S., Díaz, J., Sáez-Alonso, E., and Moriones, E. 1999. Tomato yellow leaf curl virus-Is causes a novel disease of common bean and severe epidemics in tomato in Spain. Plant Dis. 83:29-32.

Nawaz-Ul-Rehman, M. S., Nahid, N., Mansoor, S., Briddon, R. W., and Fauquet, C. M. 2010. Post-transcriptional gene silencing suppressor activity of two non-pathogenic alphasatellites associated with a begomovirus. Virology 405:300-308.

Nicot, N., Hausman, J. F., Hoffmann, L., and Evers, D. 2005. Housekeeping gene selection for real-time RT-PCR normalization in potato during biotic and abiotic stress. J. Exp. Bot. 56:2907-2914.

Noris, E., Accotto, G. P., and Luisoni, E. 1994. Advances in diagnosing Tomato yellow leaf curl geminivirus infection. Mol. Biotechnol. 2:219226.

Piroux, N., Saunders, K., Page, A., and Stanley, J. 2007. Geminivirus pathogenicity protein $\mathrm{C} 4$ interacts with Arabidopsis thaliana shaggyrelated protein kinase AtSKeta, a component of the brassinosteroid signalling pathway. Virology 362:428-440.

Polston, J. E., Cohen, S., Sherwood, R., Ben-Joseph, R., and Lapidot, M. 2006. Capsicum species: symptomless hosts and reservoirs of Tomato yellow leaf curl virus. Phytopathology 98:447-452.

Raja, P., Wolf, J. N., and Bisaro, D. M. 2010. RNA silencing directed against geminiviruses: post-transcriptional and epigenetic components. Biochim. Biophys. Acta 1799:337-351.

Reina, J., Jiménez, J., Bejarano, E. R., Guerra, J. M., Cuadrado, I. M., and García, C. 1994. El virus del rizado amarillo del tomate (TYLCV). Caracterización y diagnóstico. Hortofruticultura 5:36-40.

Reina, J., Morilla, G., Bejarano, E. R., Rodríguez, M. D., and Janssen, D. 1999. First report of Capsicum annuum plants infected by Tomato yellow leaf curl virus. Plant Dis. 83:1176-1176.

Rodrigo, G., Carrera, J., Jaramillo, A., and Elena, S. F. 2011. Optimal viral strategies for bypassing RNA silencing. J. R. Soc. Interface 8:257-268.

Rojas, M. R., Jiang, H., Salati, R., Xoconostle-Cázares, B., Sudarshama, M., Lucas, W., and Gilberstson, R. 2001. Functional analysis of proteins involved in movement of the monopartite begomovirus, Tomato yellow leaf curl virus. Virology 291:110-125. 
Rojas, M. R., Hagen, C., Lucas, W. J., and Gilbertson, R. L. 2005. Exploiting chinks in the plant's armor: evolution and emergence of geminiviruses. Annu. Rev. Phytopathol. 43:361-394.

Rotenberg, D., Thompson, T. S., German, T. L., and Willis, D. K. 2006. Methods for effective real-time RT-PCR analysis of virus-induced gene silencing. J. Virol. Methods 138:49-59.

Roye, M. E., Wernecke, M. E., McLaughlin, W. A., Nakhla, M. K., and Maxwell, D. P. 1999. Tomato dwarf leaf curl virus, a new bipartite geminivirus associated with tomatoes and peppers in Jamaica and mixed infection with Tomato yellow leaf curl virus. Plant Pathol. 48:370-378

Ruíz-Ferrer, V., and Voinnet, O. 2009. Roles of plant small RNAs in biotic stress responses. Annu. Rev. Plant Biol. 60:485-510.

Sambrook, J. R. D. 2001. Molecular Cloning: A Laboratory Manual, 2nd ed. Cold Spring Harbor Laboratory Press, Cold Spring Harbor, NY, U.S.A.

Sánchez-Campos, S., Navas-Castillo, J., Camero, R., Soria, C., Díaz, J., and Moriones, E. 1999. Displacement of Tomato yellow leaf curl virus (TYLCV)-Sr by TYLCV-Is in tomato epidemics in Spain. Phytopathology 89:1038-1043.

Sánchez-Durán, M. A., Dallas, M. B., Ascencio-Ibáñez, J. T., Reyes, M. I., Arroyo-Mateos, M., Ruíz-Albert, J., Hanley-Bowdoin, L., and Bejarano, E. R. 2011. Interaction between Geminivirus replication protein and the SUMO-conjugating enzyme is required for viral infection. J. Virol. 85:9789-9800.

Seal, S. E., Jeger, M. J., and Van den Bosch, F. 2006. Begomovirus evolution and disease management. Adv. Virus Res. 67:297-316.

Sharma, P., and Ikegami, M. 2008. RNA-silencing suppressors of geminiviruses. J. Gen. Plant Pathol. 74:189-202.

Sharma, P., and Ikegami, M. 2010. Tomato leaf curl Java virus V2 protein is a determinant of virulence, hypersensitive response and suppression of posttranscriptional gene silencing. Virology 396:85-93.

Sharma, P., Ikegami, M., and Kon, T. 2010. Identification of the virulence factors and suppressors of posttranscriptional gene silencing encoded by Ageratum yellow vein virus, a monopartite begomovirus. Virus Res. 149:19-27.

Shimura, H., Kogure, Y., Goto, K., and Masuta, C. 2008. Degree of RNA silencing and the ability of a viral suppressor vary depending on the cell species in a protoplast system. J. Gen. Plant Pathol. 74:326-330.

Silhavy, D., Molnar, A., Lucioli, A., Szittya, G., Hornyik, C., Tavazza, M., and Burgyan, J. 2002. A viral protein suppresses RNA silencing and binds silencing-generated, 21- to 25-nucleotide double-stranded RNAs. EMBO (Eur. Mol. Biol. Organ.) J. 21:3070-3080.

Sunter, G., and Bisaro, D. M. 1991. Transactivation in a geminivirus: AL2 gene product is needed for coat protein expression. Virology 180:416419 .

Sunter, G., and Bisaro, D. M. 1992. Transactivation of geminivirus AR1 and BR1 gene expression by the viral AL2 gene product occurs at the level of transcription. Plant Cell 4:1321-1331.

Takeda, A., Sugiyama, K., Nagano, H., Mori, M., Kaido, M., Mise, K., Tsuda, S., and Okuno, T. 2002. Identification of a novel RNA silencing suppressor, NSs protein of Tomato spotted wilt virus. FEBS (Fed. Eur. Biochem. Soc.) Lett. 532:75-79.
Thibivilliers, S., Joshi, T., Campbell, K. B., Scheffler, B., Xu, D., Cooper, B., Nguyen, H. T., and Stacey, G. 2009. Generation of Phaseolus vulgaris ESTs and investigation of their regulation upon Uromyces appendiculatus infection. BMC Plant Biol. 9:46.

Trinks, D., Rajeswaran, R., Shivaprasad, P. V., Akbergenov, R., Oakeley, E. J., Veluthambi, K., Hohn, T., and Pooggin, M. M. 2005. Suppression of RNA silencing by a geminivirus nuclear protein, AC2, correlates with transactivation of host genes. J. Virol. 79:2517-2527.

Van Engelen, F. A., Molthoff, J. W., Conner, A. J., Nap, J. P., Pereira, A. and Stiekema, W. J. 1995. pBINPLUS: an improved plant transformation vector based on pBIN19. Transgenic Res. 4:288-290.

Vanitharani, R., Chellappan, P., Pita, J. S., and Fauquet, C. M. 2004. Differential roles of AC2 and AC4 of cassava geminiviruses in mediating synergism and suppression of posttranscriptional gene silencing. J. Virol. 78:9487-9498.

Vanitharani, R., Chellappan, P., and Fauquet, C. M. 2005. Geminiviruses and RNA silencing. Trends Plant Sci. 10:144-151.

Van Wezel, R., Liu, H., Tien, P., Stanley, J., and Hong, Y. 2001. Gene C2 of the monopartite geminivirus Tomato yellow leaf curl virus-China encodes a pathogenicity determinant that is localized in the nucleus. Mol. Plant-Microbe Interact. 14:1125-1128.

Van Wezel, R., Dong, X., Liu, H., Tien, P., Stanley, J., and Hong, Y. 2002. Mutation of three cysteine residues in Tomato yellow leaf curl virusChina $\mathrm{C} 2$ protein causes dysfunction in pathogenesis and posttrascriptional gene-silencing suppression. Mol. Plant-Microbe Interact. 15:203208.

Voinnet, O., Vain, P., Angell, S., and Baulcombe, D. C. 1998. Systemic spread of sequence-specific transgene RNA degradation in plants is initiated by localized introduction of ectopic promoterless DNA. Cell 95:177-187.

Voinnet, O., Pinto, Y. M., and Baulcombe, D. C. 1999. Suppression of gene silencing: a general strategy used by diverse DNA and RNA viruses of plants. Proc. Natl. Acad. Sci. U.S.A. 96:14147-14152.

Voinnet, O., Lederer, C., and Baulcombe, D. 2000. A viral movement protein prevents spread of the gene silencing signal in Nicotiana benthamiana. Cell 103:157-167.

Wang, H., Buckley, K. J., Yang, X., Buchmann, R. C., and Bisaro, D. M. 2005. Adenosine kinase inhibition and suppression of RNA silencing by geminivirus AL2 and L2 proteins. J. Virol. 79:7410-7418.

Wartig, L., Kheyr-Pour, A., Noris, E., De Kouchkovsky, F., Jouanneau, F., Gronenborn, B., and Jupin, I. 1997. Genetic analysis of the monopartite tomato yellow leaf curl geminivirus: roles of V1, V2, and C2 ORF in viral pathogenesis. Virology 228:132-140.

Yang, X., Baliji, S., Buchmann, R. C., Wang, H., Lindbo, J. A., Sunter, G., and Bisaro, D. M. 2007. Functional modulation of the geminivirus AL2 transcription factor and silencing suppressor by self-interaction. J. Virol. 81:11972-11981.

Zhang, J., Dong, J., Xu, Y., and Wu, J. 2012. V2 protein encoded by Tomato yellow leaf curl China virus is an RNA silencing suppressor. Virus Res. 163:51-58.

Zrachya, A., Glick, E., Levy, Y., Arazi, T., Citovsky, V., and Gafni, Y. 2007. Suppressor of RNA silencing encoded by Tomato yellow leaf curl virusIsrael. Virology 358:159-165. 